\title{
Models for the collaborative management of African protected areas
}

Mujon Baghaia, ${ }^{a}$, Jennifer R. B. Miller ${ }^{b, c, 1, *}$, Lisa J. Blanken ${ }^{d}$, Holly T. Dublin ${ }^{\mathrm{e}}$, Kathleen H. Fitzgerald $^{\mathrm{f}}$, Patience Gandiwa ${ }^{\mathrm{g}}$, Karen Laurenson ${ }^{\mathrm{h}}$, James Milanzi ${ }^{\mathrm{i}}$, Alastair Nelson', Peter Lindsey ${ }^{\mathrm{c}, \mathrm{k}, \mathrm{l}}$

a School of Geography and the Environment, Oxford University Centre for the Environment, University of Oxford, United Kingdom

${ }^{\mathrm{b}}$ Department of Environmental Science, Policy, and Management, University of CaliforniaBerkeley, California, United States

${ }^{c}$ Panthera, New York, New York, United States

d Transboundary Use and Protection of Natural Resources in the SADC region, Deutsche Gesellschaft für Internationale Zusammenarbeit (GIZ), Gaborone, Botswana

e IUCN Eastern and Southern Africa Regional Office, Nairobi, Kenya

${ }^{\mathrm{f}}$ African Wildlife Foundation, Nairobi Kenya

g International Conventions and Transfrontier Conservation Areas Department, Zimbabwe Parks and Wildlife Management Authority Headquarters, Harare, Zimbabwe

${ }^{\mathrm{h}}$ Africa Department, Frankfurt Zoological Society, Frankfurt, Germany

${ }^{i}$ Western Region, Zambia Wildlife Authority, Chilanga, Zambia

${ }^{j}$ Wildlife Conservation Society, Maputo, Mozambique

${ }^{k}$ Mammal Research Institute, Department of Zoology and Entomology, University of Pretoria, South Africa

${ }^{1}$ Environmental Futures Research Institute, Griffith University, Queensland, Australia

${ }^{1}$ These authors contributed equally to this work

*Corresponding author: jennie.r.miller@gmail.com, +1 (707) 815-0469; 8 West 40th Street, $18^{\text {th }}$ floor, New York, NY 10018, USA 


\begin{abstract}
Africa's protected areas (PAs) are under severe and growing anthropogenic pressure. Resources for PA management are a small fraction of what is necessary in most countries, and many PAs are failing to fulfil their ecological, economic or social potential as a result. Collaborative management partnerships (CMPs), where non-profit organisations partner with state wildlife authorities, have the ability to improve PA management by facilitating longterm financial and technical support. While many have demonstrated success, there are barriers to setting up CMPs, including concern among some states that some partnerships may undermine sovereignty or appear an admission of failure. We interviewed 69 experts from state and non-profit partners about 43 PAs covering 473,861 km² in 16 African countries and analysed responses with principle component analysis to identify how partnerships differ, particularly in how they allocate governance and management responsibility. We identified three main CMP organisational structures: 1) delegated management, where a non-profit shares governance responsibility with the state and is delegated full management authority; 2) co-management, where a non-profit shares governance and management responsibility with the state; and 3) financial and technical support (advisory or implementary), where a non-profit assists the state with aspects of management without formal decision-making authority. Delegated models were associated with higher funding than co-management and financial-technical support partnerships, but models did not differ in PA land area size. Our study identifies the strengths and weaknesses of each model and offers recommendations for implementing successful CMPs, many of which are already playing a significant, positive role in conservation.
\end{abstract}

Key words: co-management; delegated management; financial-technical support; government; non-profit organization; public-private partnership 


\section{Introduction}

Terrestrial and marine protected areas (PAs) represent the "cornerstone" of global conservation efforts (Geldmann et al., 2013; Mascia et al., 2014), and are the basis for some of the most successful global conservation achievements. PAs currently cover $15.4 \%$ of the world's land — an area larger than the African continent — and 3.4\% of oceans (Juffe-Bignoli et al., 2014). Through the Convention on Biological Diversity, governments worldwide have committed to increasing PA coverage to $17 \%$ of terrestrial areas and $10 \%$ of marine areas by 2020 (Convention on Biological Diversity, 2010). Achieving that target will require strong multi-stakeholder partnerships to leverage and maintain the necessary political will and financial resources.

Africa's PA networks support the world's highest diversity and abundance of megafauna and as such, host biodiversity of substantial global value (Ripple et al., 2016). Several African nations have been highly rated on a global index of contributions towards the conservation of megafauna, due in part to the presence of large PA networks within and across countries (Lindsey et al., 2017a). However, Africa's PA network is severely threatened by ineffective management resulting from under-funding and lack of capacity (Lindsey et al., 2017b; Mansourian and Dudley, 2008; Watson et al., 2014). Acute and growing human threats, combined with inadequate financial and human resources, have contributed to widespread, steep declines in wildlife populations (Bouché et al., 2012; Craigie et al., 2010; Lindsey et al., 2014; Struhsaker et al., 2005). Elephant populations have declined significantly in several countries due to intense poaching and inadequate law enforcement, and populations of many other species are being lost due to illegal hunting for bushmeat and other wildlife products (Thouless et al., 2016). In some PAs where substantial funding exists, donor funding is nevertheless not spent effectively due to inefficiency, poor choice of focal projects and corruption (Alcorn et al., 2005; Lindsey et al., 2016; McBride et al., 2007). Donor funding that is allocated in large, non-recurrent, or inconsistent and unpredictable amounts can also fail to deliver lasting improvements in PA management (Lindsey et al., 2016). State (here used interchangeably with 'government') wildlife authorities frequently do not have the capacity to absorb such large, one-off quantities of donor funding effectively, nor the human resources necessary to deliver effective wildlife management (Bewsher et al., 2016; O’Connell et al., 2017).

The establishment of collaborative management partnerships (CMPs) between state wildlife authorities and non-profit organisations (hereafter 'non-profits') have potential to address several of these challenges. Though CMPs have existed for many decades, in recent years their number has increased in parts of Africa (Hatchwell, 2014; Nyirenda and Nkhata, 2013). This proliferation mirrors a global trend towards reduced reliance on state funding and management for PAs, increased participation by stakeholders in PA management and associated changes in legislation (Alcorn et al., 2005; Dearden et al., 2005). Given the wide array of CMPs in existence, a framework would aid in understanding the differences between various partnership models, understanding the tradeoffs between them and ultimately identifying the situations in which each model is most appropriate and likely to succeed. Such a framework, by clarifying the types of CMPs and the language used to describe them, also has potential to address concerns about CMPs that persist among some states, non-profits and 
sectors of civil society, and that may thereby inhibit CMP establishment and effectiveness (Kunambura, 2017).

Although not all CMPs are with non-profit organisations, for the purposes of this study we focused solely on partnerships between states and non-profits. While there is already a wealth of literature on CMPs between local communities and state authorities (e.g. BorriniFeyerabend et al., 2013; Carlsson and Berkes, 2005; Koontz, 2016; Lockwood et al., 2012), relatively little attention has been paid to the structure of relationships between states and non-profit partners for PA management (Dearden et al., 2005; Hatchwell, 2014). In order to understand and categorize these CMPs, we focused on two distinct and fundamentally important dimensions of PA decision-making authority: governance and management (Borrini-Feyerabend et al., 2013). Governance arrangements describe who has the power to set overall priorities and strategies, and how such decisions are made. Management, by contrast, involves the practical, day-to-day implementation of governance decisions. Most discussions about CMPs have not clearly distinguished between governance and management authority (Borrini-Feyerabend et al., 2013; Carlsson and Berkes, 2005; Dearden et al., 2005; Sen and Raakjaer Nielsen, 1996). However, whether decision-making is shared at a governance or a management level (or both) yields markedly different arrangements with varying implications. As a result, although 'co-management' is now a buzzword in conservation, it can also be a source of confusion since it encompasses a wide variety of governance and management arrangements (Lockwood et al., 2012; Zurba et al., 2012). Similarly, the terms 'public-private-partnership' and 'public-private-community-partnership' are commonly and inconsistently used to describe a broad range of relationships. Establishing a clear typology is essential for understanding the range and implications of different partnership models.

We examined CMPs as they currently exist in Africa with the goal of answering four questions: 1) Do distinct partnership models exist and if so, 2) what are their characteristics? 3) If distinct models do exist, what are the strengths and weaknesses of each, and 4) what are the conditions under which each model might be most successful? We focus our investigation on partnerships between states and non-profits across Africa and discuss the implications of our findings for PA management globally.

\section{Methods}

We focused on CMPs for the management of state-owned, terrestrial PAs in Africa. We excluded partnership arrangements for community conservation areas and between private companies and wildlife authorities where the primary objective is delivering financial profit (e.g. trophy hunting or photographic tourism). We identified as many PAs as possible in which management decision-making authority for a state PA is formally shared with or delegated to a non-profit partner. We also identified numerous partnerships in which nonprofits provide financial and technical support without formally sharing in governance or management decision-making. Because of the abundance of this latter type of PA support, we sampled only a subset of these arrangements. The sample included different types of support spread across different parts of the continent; interviews on this model were ceased when they became repetitive and no longer generated significant new insights. We identified CMPs 
through networking with professional colleagues in African governments, PA authorities, non-profits and donor sectors, and through reading peer-reviewed literature. We used snowball sampling to exhaustively pursue leads.

\subsection{Semi-structured interviews}

We conducted semi-structured interviews orally over the phone and, where this was not possible, through written surveys. We interviewed several respondent groups: a) senior officials from state wildlife authorities; b) senior management representatives from nonprofits involved in CMPs; c) park level representatives from state wildlife authorities; d) park level representatives from non-profits; and e) independent consultants working in multiple PAs. Between May 1 and October 31, 2016, we interviewed 69 respondents (Appendix S1): 22 participants from state wildlife authorities in 16 countries, 45 participants from 21 nonprofits and two independent consultants. Of our non-profit respondents, 17 were from the national and international level and 35 from the PA level (levels were not mutually exclusive since some respondents had experience at both levels). Of the state respondents, 15 were from the national level and seven from the PA level. The two independent consultant respondents worked at an international level. Respondents provided information on CMPs in 43 PAs, encompassing 473,861 $\mathrm{km}^{2}$ primarily across southern, central and eastern Africa (Fig 1, Appendix S2). Most PAs (93\%) fell in IUCN Protected Area Categories I through IV.

Respondents were asked open-ended questions about the characteristics, strengths, and weaknesses of CMPs. Questions addressed the following main themes: constraints to effective management of the PA; funding needs of PA; motivation for engaging in CMPs; how the CMP originated; description of CMP structure; legal agreement; likeliness to pursue future CMPs; and lessons learned. We asked respondents to provide answers for specific CMPs with which they had direct experience. Interviews were transcribed and answers coded into categories for analysis. Interview methods were approved in advance by Oxford University's Research Ethics Committee.

\subsection{Workshop}

To identify key elements of success in CMPs, a three-day symposium was organised to bring together a wide array of stakeholders on the topic of conservation, collaboration and management support. The symposium was organised through the Southern African Development Community (SADC) Transfrontier Conservation Area Network and attended by more than 100 experts involved in CMPs in Africa, representing wildlife authorities from 10 countries (Botswana, Kenya, Malawi, Mauritius, Mozambique, Namibia, South Africa, Swaziland, Zambia, Zimbabwe), 20 non-profits as well as the private sector, communities and bi- and multi-lateral donors (Bewsher et al., 2016). The symposium included a workshop in which delegates were divided into working groups and asked to discuss the key elements and lessons learned of three baseline CMP models: co-management, delegated management and financial-technical support partnerships (see Results for definitions). Participants also scored the aspects of each CMP model that were most important to success. We report the outcomes of these discussions qualitatively to contextualise practitioners' recommendations.

\subsection{Protected area size and funding}


To understand the geographic and financial scope in which partnership models are implemented, we examined the PA size and non-profit funding levels associated with each CMP model. We obtained PA size data from the World Database on Protected Areas (https://www.protectedplanet.net, accessed March 2017). Funding data were directly requested and obtained from the non-profit partners associated with the majority of the study PAs $(\mathrm{n}=28 ; 64 \%)$. These data represent the 'average' annual investment in management activities (converted to 2015 US\$ using a Consumer Price Index calculator, https://www.bls.gov/data/inflation_calculator, accessed July 2017) by the non-profit partner in the PA. We examined differences between CMP models by funding and size using ANOVA followed by Tukey post-hoc tests to examine pairwise differences.

\subsection{Model analysis}

We used principal component analysis (PCA) to explore correlations between CMP characteristics and identify distinct models. In preparation for analysis, interview data were compiled and synthesised by PA to identify the authority responsible for various components of governance and management. For governance, we examined the authority responsible for: 1) overall strategy, 2) oversight, and 3) hiring and firing of senior management staff. For management, we examined who had authority for: 1) lead overall management, 2) hiring and firing of general staff, 3) implementation of management actions, 4) law enforcement operations and 5) hiring and firing of law enforcement staff. We created distinct categories for law enforcement because this division was sometimes managed separately from other elements of management. We assigned the authority responsible for each of these eight categories based on a gradient of partnership relationships: 'state' (wildlife authority leads decision-making), 'independent' (state and non-profit make decisions independently, e.g. regarding their own separate staff or funds), 'shared' (state and non-profit share authority), 'special purpose entity' (an entity created jointly by the state and non-profit leads decisionmaking) and 'non-profit' (non-profit partner leads decision-making). Critically, categories were assigned based on formal decision-making power, rather than informal practice, which sometimes differed. Data were coded, normalised and scaled prior to analysis. We ran PCA analyses in the R package 'vegan' (Oksanen et al., 2017) and used the broken-stick method to identify non-trivial components (Jackson, 1993).

We assessed whether CMP characteristics formed distinct models by performing a hierarchical agglomerative cluster analysis. We ran analyses in the R packages 'vegan' using Euclidean distance and Ward linkages and found similar cluster outcomes between 'single', 'complete' and 'average' method settings (Oksanen et al., 2017). We then identified the optimal number of distinct clusters (using the 'average' cluster output for simplicity) to calculate the mean silhouette width using the R package 'cluster' (Maechler et al., 2015). All statistical analyses were run using $\mathrm{R}$ version 3.3.3 (R Core Team, 2015).

\section{Results}

PCA identified one non-trivial principal component that explained $86 \%$ of the variance (standard deviation of 2.6). Cluster analysis identified an optimal arrangement of ten models representing different types of partnerships (Fig. S1), however we combined several models with similar characteristics and closely related clustering (Fig S2). This produced five models 
representing three overarching CMP structures (Fig 1, Fig 2): delegated management, comanagement (and project co-management) and financial-technical support (comprised of advisory and implementary) (model definitions in Table 1 and following sections).

Data on non-profit partner funding were available for $50 \%(n=6)$ of delegated management, $58 \%(\mathrm{n}=7)$ of co-management, $100 \%(\mathrm{n}=1)$ of project co-management, $67 \%$ $(n=8)$ of financial-technical advisory and $83 \%(n=5)$ of financial-technical implementary PAs. The three general model types differed in non-profit funding $(\mathrm{F}(2)=5.128, \mathrm{p}=0.015)$ but not PA size $(\mathrm{F}(2)=0.613, \mathrm{p}=0.547)$, and the five detailed models did not differ by funding $(\mathrm{F}(4)=2.531, \mathrm{p}=0.071)$ or size $(\mathrm{F}(4)=0.743, \mathrm{p}=0.569$; however, we report funding and size below to show minor trends; Fig. 3). Below we outline quantitative PCA results used to identify models, as well as qualitative information synthesised from interviews and the workshop. We used these results to compile a general framework of models (Table $1)$.

\subsection{Delegated management models}

PCA identified 12 (28\% of PAs) 'delegated management' partnerships covering $61,269 \mathrm{~km}^{2}$ ( $18 \%$ of the PA land area in our survey) in eight countries (Central African Republic (CAR), Democratic Republic of Congo (DRC), Chad, Madagascar, Malawi, Republic of the Congo, Rwanda and Zambia; Figs. 1, 2). In these models, a special purpose entity is typically (but not always) created to oversee governance and management of the PA. The governance body typically operates by consensus, though the non-profit frequently nominates a majority of its members. Governance-level decisions regarding strategy and oversight are shared between the state and non-profit partner. By contrast, the non-profit partner appoints high-level management staff and has full management responsibility on the ground, which assists it in both securing and being accountable for donor funding and for conservation outcomes.

Protected areas with delegated management models were smaller than PAs in other models (mean 5,106 $\mathrm{km}^{2}$, range 538-17,600 $\mathrm{km}^{2}$ ) and had higher levels of non-profit investment (mean $\$ 1,239 / \mathrm{km}^{2}$, range $\$ 147-2,768 / \mathrm{km}^{2}$ ) than PAs in co-management and financial-technical support partnerships (Tukey post-hoc tests: $p=0.039$ and $p=0.014$, respectively; Fig. 3, Table 1). Delegated management models typically inject significant finances, which are needed to turn prospects around in PAs facing serious challenges, and non-profits generally require revenue retention at a park level. These models typically established the most comprehensive, legally-binding and long-term agreements compared to other models. They are most frequently 20-25 years with an option to renew, although one partnership agreement was for only 5 years (with automatic renewal) and another was for 50 years.

Both state and non-profit respondents recognised the major strength of delegated management as relieving states of a financial burden while delivering effective management. Non-profit partners identified the key advantage as having the ability to efficiently execute a vision for the improvement of a PA, including the ability to select high quality staff and remove non-performing or corrupt personnel. With full and direct management responsibility on the ground, non-profits are clearly accountable for delivering conservation outcomes and cannot easily shift responsibility for unachieved results to the state partner (as may occur in other models). Non-profit respondents also highlighted that delegated management models 
attract donor funding that may otherwise not be available, and suggested that they do so by offering confidence to donors that money will be well spent in countries that otherwise experience capacity, governance or corruption issues. The delegated management model thus has the potential to mobilise increased investment in PAs and associated tourism industries, which in turn can yield a "development dividend" (non-profit respondent) for remote rural areas with few alternative economic avenues. Several respondents noted that the explicit goal was to harness this large influx of investment to transform a PA and increase its financial sustainability over time. Finally, some respondents suggested that the long-term nature of delegated management arrangements can develop capacity more effectively than other models "where NGOs engage for 2-5 years and spend significant amounts of money supporting states, before exiting and letting the status quo return" (non-profit respondent).

The primary disadvantage of the delegated model is political, where some state representatives expressed resistance to delegated management due to feelings of disempowerment and loss of sovereignty, a concern of PAs appearing "sold" to foreigners or embarrassment at state management having "failed." Relatedly, there are complex issues of legitimacy when states delegate authority for law enforcement in a PA to a non-state partner. As a result, states that are willing to fully delegate management have generally only been willing to do so in the most depleted and underperforming PAs, under conditions of extreme resource limitations or in PAs with the least tourism potential.

\subsection{Co-management models}

We identified 12 PAs (33\%) in the 'co-management' model covering 113,089 $\mathrm{km}^{2}(24 \%)$ in seven countries (CAR, DRC, Mozambique, South Africa, Tanzania, Zambia and Zimbabwe; Figs. 1, 2). Structurally, co-management models may take an 'integrated' approach, in which the partners jointly create a special purpose entity, or a 'bilateral' approach, in which the government and non-profit work side by side in their existing organizational forms. Substantively, co-management arrangements involve more equal sharing of authority than delegated management, with the state and non-profit typically sharing governance responsibilities as well as some or all aspects of management. In many cases, however, law enforcement operations are formally led by the state wildlife authority, and hiring and firing of law enforcement and other staff is under the sole purview of the state wildlife authority or undertaken independently by the partners (who each employ their own personnel). PAs under co-management were larger on average than those under delegated management (mean 9,424 $\mathrm{km}^{2}$, range $390-42,000 \mathrm{~km}^{2}$ ) and involved moderate levels of non-profit funding (mean $\$ 295 / \mathrm{km}^{2}$, range $\$ 43-593 / \mathrm{km}^{2}$ ) compared to other models (Fig. 3, Table 1). One additional PA - Limpopo National Park in Mozambique - presented a related but separate additional model that we termed 'project co-management' (Fig. 2). In this model, the state and nonprofit shared governance and management authority regarding a large 'project', which supplied the vast majority of PA funding, and established special decision-making structures to do so. Responsibility for anything outside the scope of project funding remained with the state. Limpopo is moderate in size $\left(10,000 \mathrm{~km}^{2}\right)$ with a lower level of non-profit funding $\left(\$ 116 / \mathrm{km}^{2}\right.$; Fig. 3, Table 1). The basis for co-management agreements was usually legallybinding written agreements, which were typically of 10-20 years in duration, with the possibility of renewal. 
Several respondents noted that a major benefit of co-management is that the state and non-profit can capitalise on the unique strengths of each party. In the words of one non-profit representative, it "marries a local, contextual, political understanding with international, technical and financial capacity and best practice." State respondents appreciated the sharing of knowledge and expertise, along with the sharing of risk and responsibility. Additionally, some state respondents acknowledged the value of an external partner injecting fresh ideas and management styles. As with delegated management, non-profit respondents commonly stressed that co-management agreements unlock funding that would not otherwise be available. Some respondents felt that the collaborative nature of co-management projects means that they have potential to build more capacity within the state authority than other models, and are thus less vulnerable to collapse if a non-profit partner disengages. The nonprofit's formal contribution to decision-making and long-term commitment in a comanagement arrangement means that the non-profit potentially has a more transformative impact compared to financial-technical support partnerships employed in similar contexts.

Co-management shares some of the disadvantages of the other models. For example, the model is subject to some of the political sensitivities associated with delegated management. Like financial-technical support models, co-management is highly impacted in the event of a breakdown in relationships and is more exposed to political interference. The co-management model also has disadvantages that are unique to its structure. The need to align two distinct entities can lead to: confusion over roles and responsibilities; elevated risk of conflict and misunderstandings; and slower and more bureaucratic decision-making due to the need for consensus over management decisions.

\subsection{Financial-technical support models}

'Financial-technical support' partnerships comprised two models, depending on whether the non-profit played an 'implementary' (12 PAs or 27\%) or solely 'advisory' (6 PAs or 14\%) role (Figs. 1, 2). Implementary models covered $25,870 \mathrm{~km}^{2}(8 \%)$ in the Republic of the Congo, Ethiopia, Kenya and Zambia, while advisory models spanned $133,713 \mathrm{~km}^{2}(39 \%)$ in Benin, DRC, Ethiopia, Kenya, Tanzania, Uganda and Zambia (however, note that our sample of PAs using financial-technical models was not exhaustive). In this model, the state was the main authority, and in the case of advisory financial-technical partnerships, the dominant player across all categories of governance and management. In implementary financialtechnical models, non-profits played a role in the hiring and firing of some general and/or law enforcement staff, and shared implementation of some management decisions. Implementary models were used in small to moderately-sized PAs (mean 4,312 km², range 734-8,316 km²) but advisory models were implemented in PAs across a vast size range (mean 11,142 $\mathrm{km}^{2}$, range 179-32,748 $\mathrm{km}^{2}$ ) that included some of the largest parks (Fig. 3B, Table 1). Both implementary and advisory models were used in PAs with moderate levels of non-profit funding relative to other models (implementary mean of $\$ 253 / \mathrm{km}^{2}$ with range $\$ 64-575 / \mathrm{km}^{2}$ and advisory mean of $\$ 242 / \mathrm{km}^{2}$ with range $\$ 4-1365 / \mathrm{km}^{2}$; Fig. 3A, Table 1). Written agreements for financial-technical support arrangements were typically short (often 3-5 years), though frequently renewed, enabling such projects to continue for many years. Agreements frequently took the form of a simple project document or Memorandum of Understanding (MOU), allowing either partner to end the relationship with relative ease. 
Both government and non-profit respondents view the financial-technical support model as creating a flexible and potentially cost-effective arrangement that has the potential to make a significant conservation impact. These models allow for the engagement of a wide array of non-profits, including those that lack the resources or capacity to engage in co- or delegated management. Financial-technical support models were popular among state wildlife authorities, which considered them to bridge gaps in funding and human resources, and to provide an opportunity for capacity building. Both state and some non-profit respondents viewed financial-technical support models as empowering (as opposed to replacing) the state authority, and therefore recognised the state's role as "the appropriate authority in the long term" (non-profit respondent). Some non-profit respondents stressed that by engraining capacity in the local wildlife authority, these models permitted a realistic exit strategy. These models also allowed non-profits to work in areas where states were not willing to consider co-management or delegated management models - because a country already had significant capacity and resourcing of its wildlife authority, because it did not want to share power over its 'flagship' PAs (best known or highest potential tourism-value) or because it was reticent to share management over natural assets for ideological or political reasons.

A key weakness of financial and technical support models is that their loose, largely informal framework means that their success often hinges on strong personal relationships, and therefore are vulnerable if those relationships break down or if there are significant personnel changes. State respondents identified two additional weaknesses associated with the model: the vulnerability of projects to collapse if the non-profit partner leaves before local capacity has been sufficiently built, and reduced autonomy in goal-setting and resource allocation. Non-profit respondents identified lack of adequate accountability from the state partner and vulnerability to political interference as shortcomings of the model in some cases. They further indicated that financial-technical support could lead states to shift resources to less-resourced PAs, thereby undermining and weakening the baseline capacity of the partnership. Non-profits also lamented their lack of formal decision-making authority, especially regarding the power to select qualified personnel and fire non-performing or corrupt staff. This lack of decision-making authority made it more difficult to source major funding and constrained their ability to deliver conservation outcomes.

\subsection{Recommendations for success}

Workshop participants identified a series of recommendations for successful partnerships related to legal agreements, financial arrangements, governance, management, community involvement, leadership, staffing and interpersonal relationships (Appendix S3).

\section{Discussion}

Our analysis identified three overarching models of CMPs with distinct clusters of characteristics based on the degree of formal devolution of governance and management authority. These models represent a continuum of management authority allocation, with the state transferring formal management authority to a non-profit in the delegated model, sharing formal authority (to varying degrees) in the co-management model and retaining formal management authority in the financial-technical support model. Unlike management, however, governance is rarely, if ever, fully delegated. Even in delegated models, key 
elements of governance - namely strategy and oversight — are shared between the non-profit and state partners and all decisions are subject to the laws, regulations and policies established by the state. Because of this shared governance, and the unique legitimacy, influence and powers of the government partner, a clear, strong working relationship between the non-profit and state is critical to the success of all partnership models, including the delegated model. Our study also revealed that the non-profits and states that engage in delegated and co-management partnerships are often motivated by a desire for greater accountability and the potential for long-term transformation and increased financial sustainability of a PA, while those that prefer the financial-technical support model tend to have a strong philosophical belief that management and governance authority should remain vested with the state and that such a model will better enhance PA authority capacity and provide a realistic exit strategy. These results help clarify the distinctions between CMPs and identify strategies for ensuring success in future partnerships.

\subsection{Contexts in which the models occur}

Delegated management models tend to be found in the most severely under-resourced PAs, in challenging situations (such as extreme remoteness or the presence of political instability) where the capacity and resourcing of state wildlife authorities is extremely low, where there is little or no income from tourism and where wildlife populations are severely depleted or in danger of becoming so. Such extreme circumstances require significant input of resources and technical expertise, and therefore are more apt candidates for delegated management. However, more recently, African Parks has been delegated authority to manage higher profile PAs, such as Liwonde National Park in Malawi and Akagera National Park in Rwanda, which suggests a possibility that some states may be increasingly willing to engage this model more broadly. Delegated management models have not yet been attempted in exceptionally large PAs.

Co-management models offer a more equal sharing of management responsibility than delegated management arrangements. They may enable the partners to capitalise on their unique strengths, combining the political legitimacy and local knowledge of the state with the innovation, efficiencies and expertise of the non-profit sector. Such a partnership presents less risk of the state wildlife authority feeling sidelined or dominated. However, the sharing of management authority between two entities with differing organisational structures, cultures, management and leadership styles may be prone to confusion, conflict and high transaction costs. Co-management agreements have in some cases evolved from financialtechnical support partnerships that proved insufficient to achieve the partners' goals. Like the delegated model, the additional investment that comes with co-management models often leads the non-profit partner to seek greater decision-making authority, and the sharing of this authority makes the two partners accountable to each other.

Financial-technical support partnerships are found in the widest range of countries and contexts. This model has been by far the most prominent model across Africa for many decades, and several respondents indicated that the move to more devolved models like coand delegated management was as a result of long experience with the financial-technical support model and its inability in many circumstances to achieve desired outcomes. Nonetheless, it remains the most common and widespread model, and when implemented 
well in the appropriate contexts, it can be quite effective. The lack of authority of non-profits for governance and management decision-making that characterises these partnerships is a product of varied factors. First, in some countries (such as in South Africa, Botswana, Kenya, Namibia and Tanzania), there is significant state capacity, funding and commitment to managing PAs, and especially national parks. In such countries, financial-technical support "makes sense where there is solid government commitment for core management of the PA, but there are some specific threats - or challenges, or even opportunities - that the government is not able to tackle alone" (non-profit respondent) and that the non-profit can support. Second, as revealed by interviews, some countries may be reluctant to engage in models that involve sharing or delegating authority because of political and post-colonial sensitivities. Third, some non-profits do not have adequate resources or expertise to take on significant management responsibility. Finally, some non-profits believe that their proper role is to support (not supplant) the state, which they see as the appropriate management authority for PAs, even where capacity is low.

\subsection{Caveats to our model framework}

The breakdown of current examples into these three models is not clear-cut and our framework, by necessity, oversimplifies the complexity of CMPs in several ways. First, the variation among CMPs is more akin to a continuum of possibilities rather than discreet categories, and some examples fall on the borderlines of these constructed types. For example, Virunga National Park in DRC, categorised as a co-management model, could alternatively be considered delegated management because the Chief Warden of the park comes from the non-profit partner and oversees general and law enforcement management decisions (though he shares other decisions with the wildlife authority). Second, in some cases models differ on paper and in practice. For example, in practice some financialtechnical support models approximate co-management, due to the non-profit providing the majority of funding to a PA and having authority on how money is spent, and in others due to the state authority developing trust in the partner over time. Third, models may evolve over time. Across Africa, many partnerships are gradually shifting from financial-technical support towards co-management and delegated management due to recognition of the severe capacity constraints experienced by some state partners. It is further envisioned that, if successful, these more devolved models will in the future 'hand back' authority to the state. Finally, the purpose of partnerships may vary, further complicating the categorisation of models. For example, in the case of Marakele National Park in South Africa, co-management is used as a tool to extend the area of land under protection, rather than as a means to improve the management of an existing PA.

Our study represents a first attempt to qualitatively and quantitatively identify the models of CMPs that are operational for the management of state-owned PAs in Africa and to understand the strengths and weaknesses of these different models. Additional research is needed to examine the effectiveness of different approaches on inter alia the conservation status of PAs, national capacity for PA management and revenue generation.

\subsection{The case for non-profits to engage in CMPS}


Human pressures on Africa's wildlife are growing and a rising proportion of PAs are becoming depleted (Craigie et al., 2010; Lindsey et al., 2017). In Africa, PAs are likely to become increasingly important for conservation as human populations expand and occupy unprotected lands. Countries are at risk of losing valuable wildlife, ecosystem services and natural resources, even within PAs, before significant benefits can be derived from those resources via tourism and other mechanisms (Lindsey et al., 2017). If PAs are not able to fulfil basic ecological functions and do not contribute significantly to local or national economies, there is likely to be increasing political pressure for converting such land to alternative uses. Worryingly, a substantial number of African PAs have already been downsized or degazetted (Mascia et al., 2014); more are likely to follow unless their economic contributions significantly increase to effectively outcompete alternative land use options.

Providing support to PA management arguably represents one of the most direct ways in which the donor community can improve the prospects for conservation in Africa. Numerous studies have highlighted the importance of strong management budgets for effective conservation of African PA (Henschel et al., 2016; Leader-Williams et al., 1990; Lindsey et al., 2017b; Packer et al., 2013). Investing in PAs, particularly through the framework of CMPs, has the potential to yield direct conservation benefits and in some cases significant social and economic benefits by providing a platform from which to develop more sustainable wildlife-based economies. Tourism specifically has the potential to meaningfully support GDP growth, to create large numbers of jobs and promote development in remote areas where few other economic activities are available (Lindsey et al., 2012; Makochekanwa, 2013; Uddhammar, 2006; World Travel \&Tourism Council, 2016). In addition, PAs protect critical ecosystem services upon which people and economies depend. Further, the long-term presence of a non-profit working in remote areas and strengthening law enforcement and natural resource governance through engagement with local government and communities often leads to improved governance and security.

Interviews suggest that donor and non-profit interest in more devolved CMPs - comanagement and delegated management partnerships - is on the rise. Numerous interviewees highlighted the fact that these models attract important additional sources of institutional and philanthropic funding. Indeed, donors were sometimes quite strong in their commitment to funding more devolved models and in some cases require co- or delegated management agreements prior to investing in PAs. Several international non-profits are increasing their engagement in co- and delegated management models (e.g. African Parks Network, African Wildlife Foundation, Frankfurt Zoological Society, Peace Parks Foundation, Wildlife Conservation Society), as are several smaller-scale non-profits focusing on single PAs. Of the international non-profits interviewed, $78 \%$ (seven out of nine) were looking to undertake a co- or delegated management arrangement either in PAs they already supported with another model or in entirely new PAs. However, a large number of PAs currently lack any support and much greater levels of support and engagement are required from the donor community. For these reasons, we urge the international development community (as well as the conservation community) to consider investing in CMPs as a means of simultaneously promoting sustainable rural development and environmental conservation. 
We would be remiss if we did not acknowledge that such partnerships provide nonprofits significant benefits, including increased funding and profile. However, it is equally important to note that by assuming management responsibility - particularly in co- and delegated management models - nonprofits also increase their reputational risk and become directly accountable for delivering positive conservation outcomes.

\subsection{The case for African governments to engage in CMPs}

As mentioned, wildlife and PA networks can represent crucially important assets for African countries. Some PAs provide vital ecological services such as watershed protection and carbon sequestration and can act as the basis for tourism industries that have potential to both grow and diversify economies (Lindsey et al., 2014; Watson et al., 2014). CMPs offer African states the opportunity to share the burden of managing their vast PA estates. External funding and assistance channeled through CMPs have the potential to improve the prospects of effective conservation of Africa's natural assets. The variety of models available allows CMPs to be applied across a wide range of contexts. In cases where the state wildlife authority is relatively well funded but lacks the resourcing to achieve optimal PA performance, or where staffing numbers or specific skill sets are lacking, financial-technical support models remain important. In PAs where a higher and more sustained injection of funding is required, but where the state wildlife authority has the desire and capacity to maintain an active role on the ground, co-management arrangements represent a potentially useful approach. In situations where PAs and the wildlife authority are extremely poorly resourced, or where the state believes 'outsourcing' PA management to a specialised organisation is the most effective way to secure or even transform its PA estate, the delegated management model has demonstrated potential (Fearnhead, 2009). In summary, CMPs have potential to provide African states with a number of opportunities and benefits.

Our study also addresses some government concerns about CMPs. For example, we found no evidence that a country's sovereignty or ownership of PAs was diminished as a result of a partnership. It should be underscored that CMPs relate to governance and management, not ownership, of PAs. Moreover, all CMPs studied are subject to a state's laws and sovereign authority. Even when management was fully delegated, the state usually shared governance decision-making authority over the strategic direction of the PA, and effectively engaged an outside entity to manage it on a day-to-day basis, under its oversight, and for a well-defined and limited period of time. Moreover, without a willing, supportive and engaged state partner, even a strong delegated model "is doomed to fail" (non-profit respondent) since important activities, including securing permits and permissions, engaging local communities and dealing with complex law enforcement issues and policy considerations require a committed government partner. We urge African states to see CMPs as an opportunity and a strategic approach to access international willingness to pay for African conservation, to facilitate capacity-building, and ultimately to help fulfil their national and international obligations. We further urge African states to strive for clarity on the types of models that they are comfortable with for different sections of their PA estates, to establish a streamlined process for engaging partners and to actively solicit partners to assist with the management of PAs where support is most needed and has the most potential. Although different models may 
be appropriate for different PAs, some degree of consistency between agreements will decrease the monitoring and management burden on the PA authority.

\subsection{The need for best practice guidelines}

Given the vast area over which CMPs are practiced, and the potential they confer for enhancing the conservation prospects of PAs in Africa and elsewhere if implemented well, we recommend that the International Union for Conservation of Nature (IUCN) establish a set of best-practice guidelines. Such guidelines would assist donors, prospective non-profit partners and state wildlife authorities by allowing them to learn from the mistakes and successes of others (Rutagarama and Martin, 2006). A dedicated group of experts could further strengthen the implementation of these guidelines to encourage information sharing and collaboration.

In summary, CMPs provide a direct and potentially effective means for the international community, donors, and non-profits to contribute to conservation, economic development and governance in Africa. For African states, CMPs offer potential to build local capacity, share the financial burden associated with managing vast PA estates and increase the ecological and economic benefits derived from PAs. We encourage both African states and the non-profit community to engage in these models using best practice. We also urge the research community to investigate the relative efficacy of the various models, to contribute to improving the proposed framework and to help understand how the effectiveness of CMPs might be enhanced.

\section{Acknowledgements}

The authors would like to thank the SADC Transfrontier Conservation Area Network, the attendees at the workshop and all interviewees and respondents for their valuable inputs and recommendations. We acknowledge with thanks the Deutsche Gesellschaft für Internationale Zusammenarbeit (GIZ) implementing on behalf of the German Federal Ministry for Economic Cooperation and Development (BMZ) and the German Federal Ministry for Environment, Nature Conservation, Building and Nuclear Safety (BMUB), as well as the African Wildlife Foundation, Peace Parks Foundation and Range Wide Conservation Programs for Cheetah and African Wild Dogs for financial contributions to the workshop. JRBM was supported in part by National Science Foundation Coupled Human and Natural Systems Grant 115057. We are especially grateful to Paul Bewsher, Rob Malpas and Nidhi Ramsden for their support in conceptualizing the work presented in this paper.

\section{Supplementary Information}

Appendix S1. Respondent information.

Appendix S2. Protected area names.

Appendix S3. Recommendations for successful collaborative management partnerships.

Figure S1. Results from silhouette width analysis.

Figure S2. Principle component analysis dendrogram.

\section{References}

Alcorn, J., Luque, A., Weisman, W., Suralaga, D., Singh, S., Zeballos, R., Rodriguez, L., 
Murombedzi, J., Huskova, B., Rothschild, D., Murphree, M., Brosius, P., 2005. Nongovernmental organizations and protected area governance, in: Pansky, D. (Ed.), Governance Stream of the Vth World Park Congress. Canada, Parks Canada and IUCN World Commission on Protected Areas (WCPA), Ottawa and Gland, pp. 1-44.

Bewsher, P., Blanken, L.J., Dublin, H., Laurenson, K., Lindsey, P.A., Malpas, R., Mentzel,

C., Ramsden, N., 2016. Technical report of SADC TFCA Network Symposium 2016:

Conservation, Collaboration \& Management Support. Gaborone, Botswana.

Borrini-Feyerabend, G., Dudley, N., Jaeger, T., Lassen, B., Pathak Broome, N., Phillips, A., Sandwith, T., 2013. Governance of Protected Areas: From Understanding to Action, Best Practice Protected Area Guideline Series No. 20.

Bouché, P., Nzapa Mbeti Mange, R., Tankalet, F., Zowoya, F., Lejeune, P., Vermeulen, C., 2012. Game over! Wildlife collapse in northern Central African Republic. Environ.

Monit. Assess. 184, 7001-7011. doi:10.1007/s10661-011-2475-y

Carlsson, L., Berkes, F., 2005. Co-management: Concepts and methodological implications.

J. Environ. Manage. 75, 65-76. doi:10.1016/j.jenvman.2004.11.008

Convention on Biological Diversity, 2010. X/2. The Strategic Plan for Biodiversity 2011-

20120 and the Aichi Biodiversity Targets. Nagoya, Japan.

Craigie, I.D., Baillie, J.E.M., Balmford, A., Carbone, C., Collen, B., Green, R.E., Hutton, J.M., 2010. Large mammal population declines in Africa's protected areas. Biol.

Conserv. 143, 2221-2228. doi:10.1016/j.biocon.2010.06.007

Dearden, P., Bennett, M., Johnston, J., 2005. Trends in global protected area governance, 1992-2002. Environ. Manage. 36, 89-100. doi:10.1007/s00267-004-0131-9

Fearnhead, P., 2009. Privately management protected areas., in: Suich, H., Child, B.,

Spenceley, A. (Eds.), Privately Managed Protected Areas. Evolution and Innovation in Wildlife Conservation: Parks and Game Ranches to Transfrontier Conservation Areas. Earthscan, Oxon, UK and New York, USA, pp. 409-428.

Geldmann, J., Barnes, M., Coad, L., Craigie, I.D., Hockings, M., Burgess, N.D., 2013. Effectiveness of terrestrial protected areas in reducing habitat loss and population declines. Biol. Conserv. 161, 230-238. doi:10.1016/j.biocon.2013.02.018

Hatchwell, M., 2014. Public-private partnerships as a management option for protected areas. Anim. Conserv. 17, 3-4. doi:10.1111/acv.12098

Henschel, P.H., Petracca, L.S., Hunter, L.T.B., Kiki, M., Sewadé, C., Tehou, A., Robinson, H.S., 2016. Determinants of distribution patterns and management needs in a critically endangered lion Panthera leo population. Front. Ecol. Evol. 4.

doi: $10.3389 /$ fevo. 2016.00110

Jackson, D.A., 1993. Stopping rules in Principal Components Analysis: A comparison of heuristical and statistical approaches. Ecology 74, 2204-2214.

Juffe-Bignoli, D., Burgess, N.D., Bingham, H., Belle, E.M.S., de Lima, M.G., Deguignet, M., Bertzky, B., Milam, A., Martinez-Lopez, J., Lewis, E., Eassom, A., Wicander, S., Geldmann, J., van Soesbergen, A., Arnell, A., O’Connor, B., Park, S., Shi, Y.N., Danks, F.S., MacSharry, B., Kingston, N., 2014. Protected Planet Report 2014, Protected Planet Report. UNEP-WCMC, Cambridge, UK. doi:DEW/1233/CA

Koontz, T., 2016. Back to the Future? Collaborative Environmental Governance Theory and Practice, in: Margerum, R., Robinson, C. (Eds.), The Challenges of Collaboration in 
Environmental Governance: Barriers and Responses. Edward Elgar Publishing Limited, Glos, UK, pp. 54-80.

Kunambura, A., 2017. Germans take control of Gonarezhou. Financ. Gaz.

Leader-Williams, N., Albon, S.D., Berry, P., 1990. Illegal exploitation of black rhinoceros

and elephant populations: Patterns of decline, law enforcement and patrol effort in Laungwa Valley, Zambia. J. Appl. Ecol. 27, 1055-1087.

Lindsey, P.A., Balme, G., Booth, V.R., Midlane, N., 2012. The significance of African lions

for the financial viability of trophy hunting and the maintenance of wild land. PLoS One

7. doi:10.1371/journal.pone.0029332

Lindsey, P.A., Balme, G., Funston, P.J., Henschel, P.H., Hunter, L.T.B., 2016. Life after

Cecil: channelling global outrage into funding for conservation in Africa. Conserv. Lett.

9, 296-301. doi:10.1007/s13398-014-0173-7.2

Lindsey, P.A., Nyirenda, V., Barnes, J.I., Becker, M.S., McRobb, R., Tambling, C.J., Taylor,

W.A., Watson, F.G., t'Sas-Rolfes, M., 2014. Underperformance of African protected area networks and the case for new conservation models: Insights from Zambia. PLoS

One 9. doi:10.1371/journal.pone.0094109

Lindsey, P.A., Petracca, L.S., Burnham, D., Hayward, M.W., Henschel, P.H., Hinks, A.E., Garnett, S.T., Macdonald, D.W., Macdonald, E.A., Ripple, W.J., Zander, K., Dickman, A.J., 2017a. Relative efforts of countries to conserve world's megafauna. Glob. Ecol. Conserv. 10, 243-252. doi:10.1016/j.gecco.2017.03.003

Lindsey, P.A., Petracca, L.S., Funston, P.J., Bauer, H., Dickman, A.J., Everatt, K., Flyman, M., Henschel, P.H., Hinks, A.E., Kasiki, S., Loveridge, A., Macdonald, D.W., Mandisodza, R., Mgoola, W., Miller, S.M., Nazerali, S., Siege, L., Uiseb, K., Hunter, L.T.B., 2017b. The performance of African protected areas for lions and their prey. Biol. Conserv. 209, 137-149. doi:10.1016/j.biocon.2017.01.011

Lockwood, M., Davidson, J., Hockings, M., Haward, M., Kriwoken, L., 2012. Marine biodiversity conservation governance and management: Regime requirements for global environmental change. Ocean Coast. Manag. 69, 160-172.

doi:10.1016/j.ocecoaman.2012.07.015

Maechler, M., Rousseeuw, P., Struyf, A., M., H., Hornik, K., 2015. Cluster: Cluster Analysis Basics and Extensions.

Makochekanwa, A., 2013. An analysis of tourism contribution to economic growth in SADC Countries. Botswana J. Econ. 11, 42-56.

Mansourian, S., Dudley, N., 2008. Public Funds to Protected Areas. WWF Int. 1-43.

Mascia, M.B., Pailler, S., Krithivasan, R., Roshchanka, V., Burns, D., Mlotha, M.J., Murray, D.R., Peng, N., 2014. Protected area downgrading, downsizing, and degazettement (PADDD) in Africa, Asia, and Latin America and the Caribbean, 1900-2010. Biol. Conserv. 169, 355-361. doi:10.1016/j.biocon.2013.11.021

McBride, M.F., Wilson, K.A., Bode, M., Possingham, H.P., 2007. Incorporating the effects of socioeconomic uncertainty into priority setting for conservation investment. Conserv. Biol. 21, 1463-1474.

Nyirenda, V., Nkhata, B.A., 2013. Collaborative governance and benefit sharing In Liuwa Plain National Park, western Zambia. Parks 19, 103-114.

O’Connell, M.J., Nasirwa, O., Carter, M., Farmer, K.H., Appleton, M., Arinaitwe, J., 
Bhanderi, P., Chimwaza, G., Copsey, J., Dodoo, J., Duthie, A., Gachanja, M., Hunter, N., Karanja, B., Komu, H.M., Kosgei, V., Kuria, A., Magero, C., Manten, M., Mugo, P., Müller, E., Mulonga, J., Niskanen, L., Nzilani, J., Otieno, M., Owen, N., Owuor, J., Paterson, S., Regnaut, S., Rono, R., Ruhiu, J., Theuri Njoka, J., Waruingi, L., Waswala Olewe, B., Wilson, E., 2017. Capacity building for conservation: problems and potential solutions for sub-Saharan Africa. Oryx 1-11. doi:10.1017/S0030605317000291

Oksanen, J., Blanchet, F.G., Friendly, M., Kindt, R., Legendre, P., McGlinn, D., Minchin, P.R., O’Hara, R.B., Simpson, G.L., Solymos, P., Stevens, M. Henry H. Szoecs, E., Wagner, H., 2017. Vegan: Community Ecology Package.

Packer, C., Loveridge, A.J., Canney, S., Caro, T.M., Garnett, S.T., Pfeifer, M., Zander, K.K., Swanson, A., MacNulty, D., Balme, G., Bauer, H., Begg, C.M., Begg, K.S., Bhalla, S., Bissett, C., Bodasing, T., Brink, H., Burger, A., Burton, A.C., Clegg, B., Dell, S., Delsink, A., Dickerson, T., Dloniak, S.M., Druce, D., Frank, L., Funston, P.J., Gichohi, N., Groom, R., Hanekom, C., Heath, B., Hunter, L.T.B., Deiongh, H.H., Joubert, C.J., Kasiki, S.M., Kissui, B., Knocker, W., Leathem, B., Lindsey, P.A., MacLennan, S.D., McNutt, J.W., Miller, S.M., Naylor, S., Nel, P., Ng’weno, C., Nicholls, K., Ogutu, J.O., Okot-Omoya, E., Patterson, B.D., Plumptre, A., Salerno, J., Skinner, K., Slotow, R., Sogbohossou, E.A., Stratford, K.J., Winterbach, C., Winterbach, H., Polasky, S., 2013. Conserving large carnivores: Dollars and fence. Ecol. Lett. 16, 635-641. doi:10.1111/ele.12091

R Core Team, 2015. R: A language and environment for statistical computing.

Rutagarama, E., Martin, A., 2006. Partnerships for protected area conservation in Rwanda. Geogr. J. 172, 291-305.

Sen, S., Raakjaer Nielsen, J., 1996. Fisheries co-management: a comparative analysis. Mar. Policy 20, 405-418. doi:10.1016/0308-597X(96)00028-0

Struhsaker, T.T., Struhsaker, P.J., Siex, K.S., 2005. Conserving Africa's rain forests: Problems in protected areas and possible solutions. Biol. Conserv. 123, 45-54. doi:10.1016/j.biocon.2004.10.007

Thouless, C.R., Dublin, H.T., Blanc, J.J., Skinner, D.P., Daniel, T.E., Taylor, R.D., Maisels, F., Frederick, H.L., Bouche, P., 2016. African Elephant Status Report 2016. Gland, Switzerland.

Uddhammar, E., 2006. Development, conservation and tourism: conflict or symbiosis? Rev. Int. Polit. Econ. 13, 656-678. doi:10.1080/09692290600839923

Watson, J.E.M., Dudley, N., Segan, D.B., Hockings, M., 2014. The performance and potential of protected areas. Nature 515, 67-73. doi:10.1038/nature13947

World Travel \&Tourism Council, 2016. Travel \& Tourism: Economic Impact 2016 World. London.

Zurba, M., Ross, H., Izurieta, A., Rist, P., Bock, E., Berkes, F., 2012. Building comanagement as a process: Problem solving through partnerships in Aboriginal Country, Australia. Environ. Manage. 49, 1130-1142. doi:10.1007/s00267-012-9845-2 
Table 1. Model framework for collaborative management partnerships.

\begin{tabular}{|c|c|c|c|c|}
\hline \multirow[t]{2}{*}{ Model } & \multicolumn{2}{|c|}{ Division of authority between partners } & \multirow{2}{*}{$\begin{array}{l}\text { Size relative } \\
\text { to PA sample } \\
\quad \text { (range) }\end{array}$} & \multirow{2}{*}{$\begin{array}{l}\text { Relative non-profit } \\
\text { funding (mean and } \\
\text { range in sample) }\end{array}$} \\
\hline & Governance & Management & & \\
\hline $\begin{array}{l}\text { Delegated } \\
\text { management }\end{array}$ & $\begin{array}{l}\text { Strategy and oversight typically } \\
\text { handled by a special purpose entity } \\
\text { created by both partners; non-profit } \\
\text { typically appoints park manager }\end{array}$ & Run by non-profit & $\begin{array}{c}\text { Small to } \\
\text { moderate } \\
(538-17,600 \\
\left.\mathrm{km}^{2}\right)\end{array}$ & $\begin{array}{c}\text { High } \\
\left(\$ 1200 / \mathrm{km}^{2}, \$ 150-\right. \\
\left.2800 / \mathrm{km}^{2}\right)\end{array}$ \\
\hline Co-management & $\begin{array}{l}\text { Shared, to varying degrees, between } \\
\text { state and non-profit (may or may not } \\
\text { include the creation of a special } \\
\text { purpose entity) }\end{array}$ & $\begin{array}{l}\text { Shared, to varying degrees, between state and non- } \\
\text { profit; except in some cases for management of law } \\
\text { enforcement (run by state) and employing personnel } \\
\text { (particularly law enforcement personnel), which may } \\
\text { be run by the state or independently by the partners }\end{array}$ & $\begin{array}{l}\text { Small to } \\
\text { large } \\
(390-42,000 \\
\left.\mathrm{km}^{2}\right)\end{array}$ & $\begin{array}{c}\text { Moderate } \\
\left(\$ 300 / \mathrm{km}^{2}, \$ 40-\right. \\
\left.600 / \mathrm{km}^{2}\right)\end{array}$ \\
\hline $\begin{array}{l}\text { Project co- } \\
\text { management }\end{array}$ & $\begin{array}{l}\text { State leads strategy and oversight, } \\
\text { with involvement and consensus of } \\
\text { non-profit on project-related areas; } \\
\text { joint Steering Committee appoints } \\
\text { project leadership }\end{array}$ & $\begin{array}{l}\text { State oversees management of law enforcement and } \\
\text { management of all staff; shares authority with non- } \\
\text { profit for all project-related and project-funded } \\
\text { decisions }\end{array}$ & $\begin{array}{c}\text { Moderate } \\
\left(10,000 \mathrm{~km}^{2}\right)\end{array}$ & $\begin{array}{c}\text { Low } \\
\left(\$ 116 / \mathrm{km}^{2}\right)\end{array}$ \\
\hline $\begin{array}{l}\text { Financial-technical } \\
\text { support } \\
\text { (implementary) }\end{array}$ & State is main authority & $\begin{array}{l}\text { State is main authority; non-profit plays varying roles } \\
\text { to support shared goals, employing personnel and } \\
\text { helping to implement management decisions }\end{array}$ & $\begin{array}{l}\text { Small to } \\
\text { moderate } \\
(734-8,316 \\
\left.\mathrm{km}^{2}\right)\end{array}$ & $\begin{array}{c}\text { Moderate } \\
\left(\$ 250 / \mathrm{km}^{2}, \$ 60-\right. \\
\left.600 / \mathrm{km}^{2}\right)\end{array}$ \\
\hline $\begin{array}{l}\text { Financial-technical } \\
\text { support (advisory) }\end{array}$ & State is main authority & State is main authority & $\begin{array}{c}\text { Small to } \\
\text { large } \\
(179-32,748 \\
\left.\mathrm{km}^{2}\right) \\
\end{array}$ & $\begin{array}{c}\text { Moderate } \\
\left(\$ 250 / \mathrm{km}^{2}, \$ 5-\right. \\
\left.1400 / \mathrm{km}^{2}\right)\end{array}$ \\
\hline
\end{tabular}




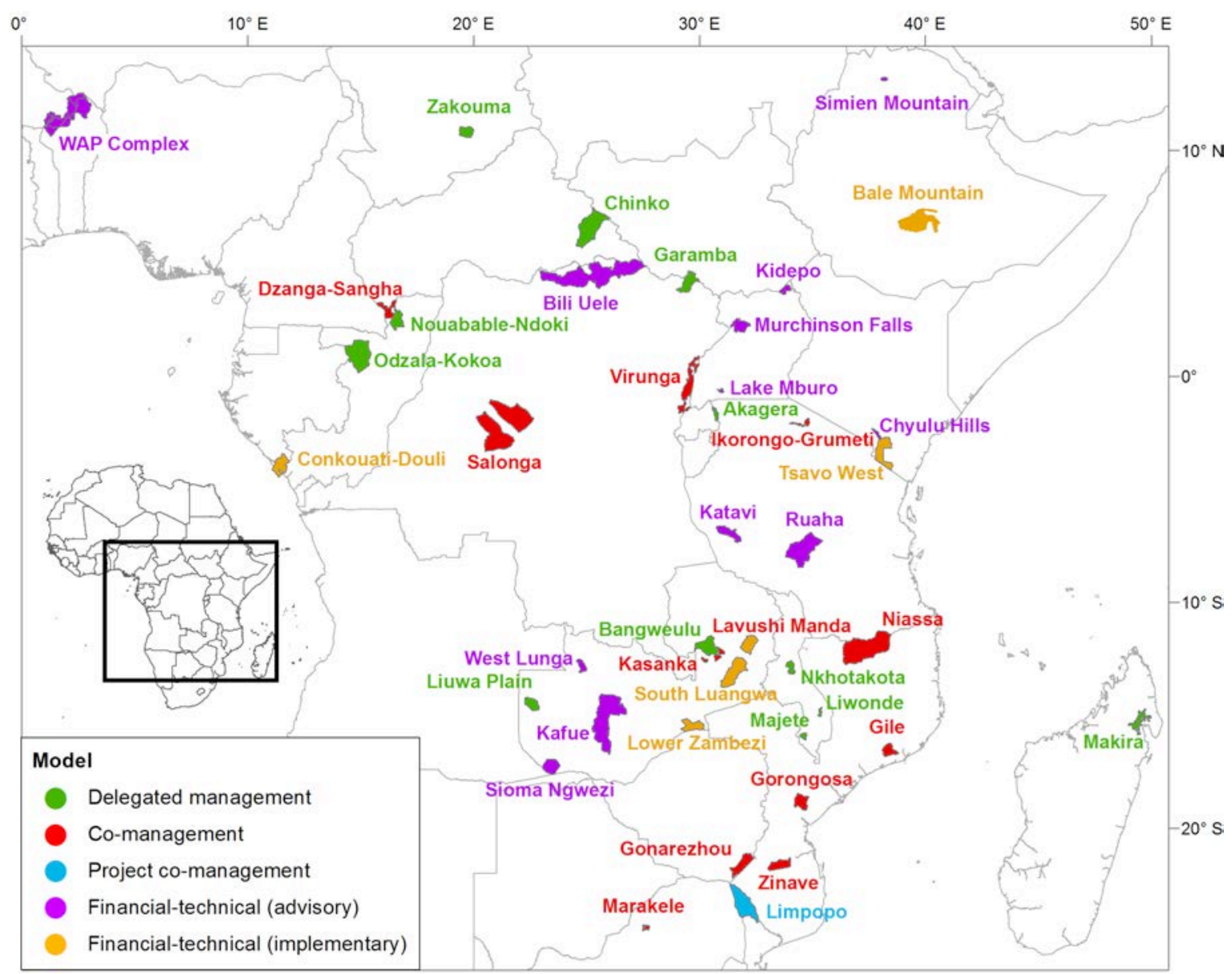

Figure 1. Map of the protected areas included in the study, with colour indicating the model of collaborative partnership. 

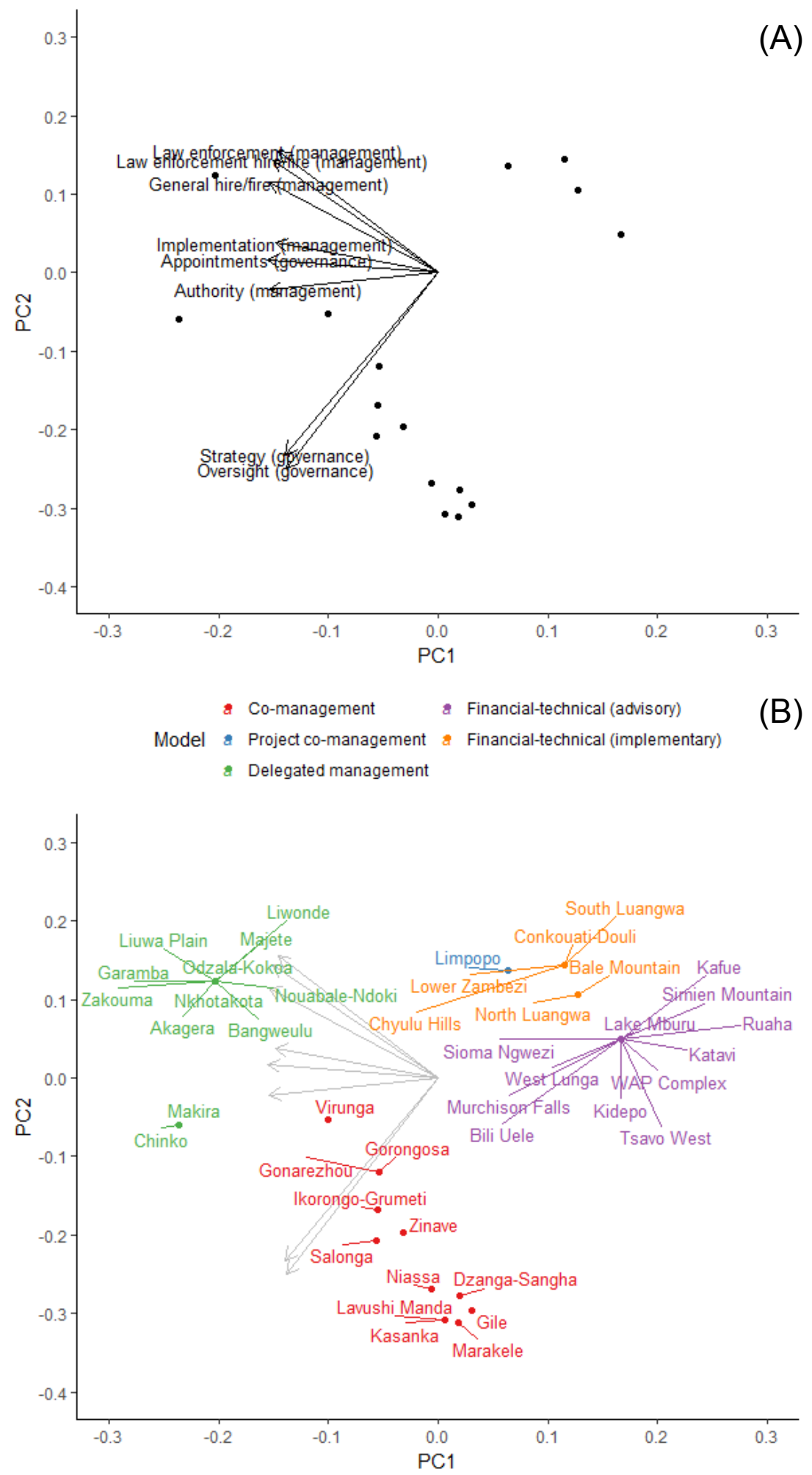

Figure 2. Principal components analysis (PCA) biplots. Panel A shows the relative scores and associated eigenvectors of eight collaborative management partnership characteristics on the first two principal components. Panel B shows data points representing scores of 43 protected areas clustered and coloured by model type. 

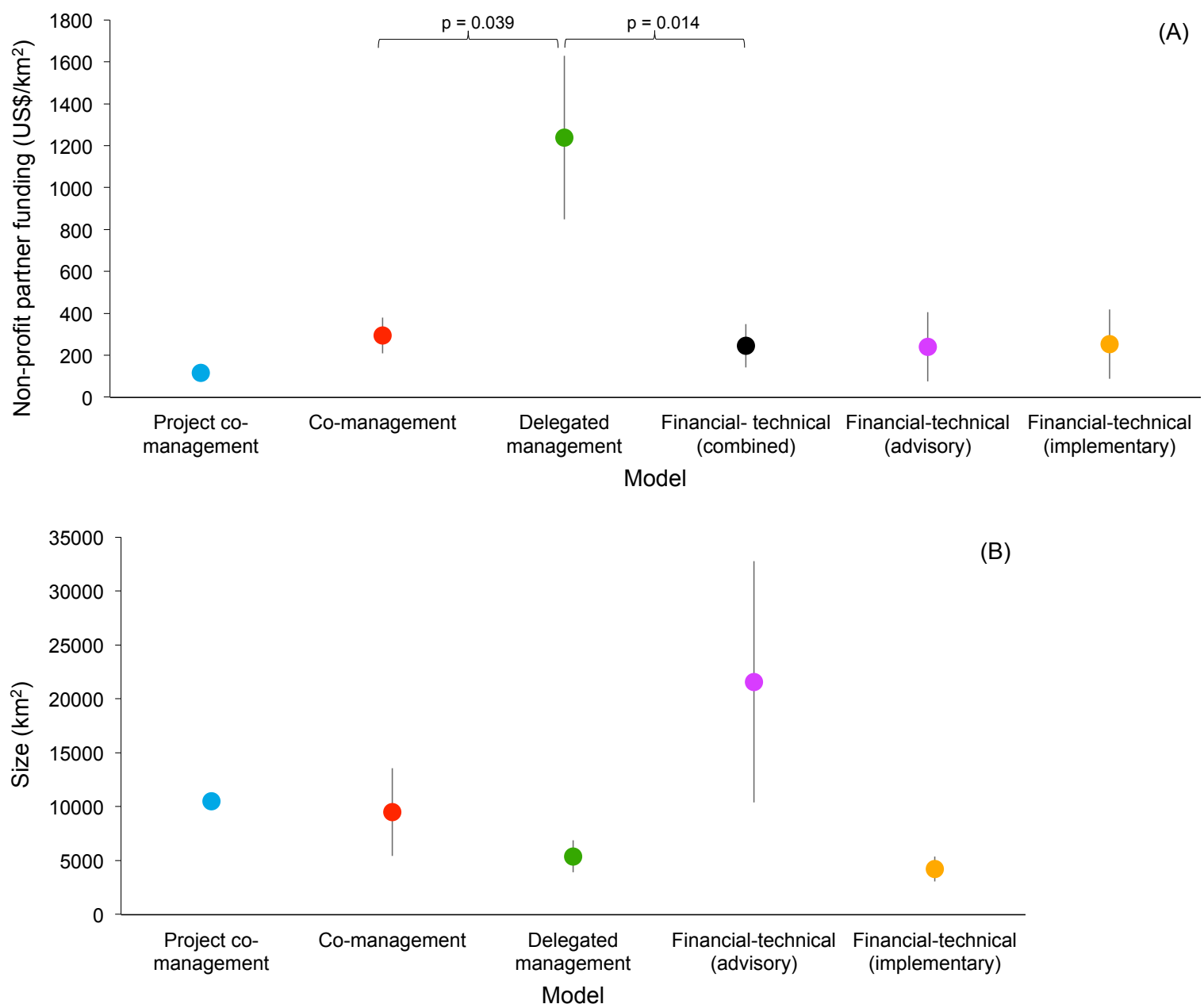

Figure 3. The financial and geographical scope of collaborative partnership models, showing (A) non-profit partner funding levels and (B) the average land area size of protected areas. Vertical lines represent standard error. P-values indicate statistical differences in funding between delegated management and co-management, and between delegated management and financial-technical (combined) (A); models did not differ in size (B). Values in B represent all protected areas in study; values in $A$ are based on a subset of the protected areas for which funding data was available: project co-management $\left(\mathrm{n}_{\mathrm{A}}=1 ; \mathrm{n}_{\mathrm{B}}=1\right)$; comanagement $\left(\mathrm{n}_{\mathrm{A}}=7 ; \mathrm{n}_{\mathrm{B}}=12\right)$; financial-technical (combined) $\left(\mathrm{n}_{\mathrm{A}}=13\right)$; financial-technical (advisory) $\left(\mathrm{n}_{\mathrm{A}}=8 ; \mathrm{n}_{\mathrm{B}}=12\right)$; financial-technical (implementary) $\left(\mathrm{n}_{\mathrm{A}}=5 ; \mathrm{n}_{\mathrm{B}}=6\right)$. 


\section{Appendix A. Supplementary Data}

Models for the collaborative management of African protected areas

\section{Biological Conservation}

Mujon Baghai, Jennifer R. B. Miller, Lisa J. Blanken, Holly T. Dublin, Kathleen H. Fitzgerald, Patience Gandiwa, Karen Laurenson, James Milanzi, Alastair Nelson, Peter Lindsey

Table S1. Respondent information.

\begin{tabular}{|c|c|c|c|c|}
\hline ID & Sector & Organisation & Level of expertise & Country \\
\hline 1 & Gov't & $\begin{array}{l}\text { Department of Wildlife and } \\
\text { National Parks }\end{array}$ & National & Botswana \\
\hline 2 & Gov't & $\begin{array}{l}\text { Ministry of Wildlife, Water } \\
\text { and Forestry }\end{array}$ & National & CAR \\
\hline 3 & Gov't & $\begin{array}{l}\text { Ministry of Environment and } \\
\text { Water }\end{array}$ & National & Chad \\
\hline 4 & Gov't & $\begin{array}{l}\text { Institut Congolais pour la } \\
\text { Conservation de la Nature }\end{array}$ & National & DRC \\
\hline 5 & Gov't & Kenya Wildlife Service & National & Kenya \\
\hline 6 & Gov't & $\begin{array}{l}\text { Ministry of Environment, } \\
\text { Ecology, and Forests }\end{array}$ & National & Madagascar \\
\hline 7 & Gov't & $\begin{array}{l}\text { Department of National Parks } \\
\text { and Wildlife }\end{array}$ & National & Malawi \\
\hline 8 & Gov't & $\begin{array}{l}\text { Department of National Parks } \\
\text { and Wildlife }\end{array}$ & National & Malawi \\
\hline 9 & Gov't & $\begin{array}{l}\text { National Agency for } \\
\text { Conservation Areas (ANAC) }\end{array}$ & National & Mozambique \\
\hline 10 & Gov't & $\begin{array}{l}\text { Ministry of Environment and } \\
\text { Tourism }\end{array}$ & National & Namibia \\
\hline 11 & Gov't & South African National Parks & National & South Africa \\
\hline 12 & Gov't & $\begin{array}{l}\text { Swaziland National Trust } \\
\text { Commission }\end{array}$ & National & Swaziland \\
\hline 13 & Gov't & $\begin{array}{l}\text { Wildlife Division, Ministry of } \\
\text { Natural Resources and } \\
\text { Tourism }\end{array}$ & National & Tanzania \\
\hline 14 & Gov't & $\begin{array}{l}\text { Department of National Parks } \\
\text { and Wildlife }\end{array}$ & National & Zambia \\
\hline 15 & Gov't & $\begin{array}{l}\text { Zimbabwe Parks and Wildlife } \\
\text { Management Authority }\end{array}$ & National & Zimbabwe \\
\hline 16 & Gov't & $\begin{array}{l}\text { Institut Congolais pour la } \\
\text { Conservation de la Nature }\end{array}$ & PA & DRC \\
\hline 17 & Gov't & $\begin{array}{l}\text { Ethiopian Wildlife } \\
\text { Conservation Authority }\end{array}$ & PA & Ethiopia \\
\hline 18 & Gov't & $\begin{array}{l}\text { National Agency for } \\
\text { Conservation Areas (ANAC) }\end{array}$ & PA & Mozambique \\
\hline
\end{tabular}




\begin{tabular}{|c|c|c|c|c|}
\hline ID & Sector & Organisation & Level of expertise & Country \\
\hline 19 & Gov't & $\begin{array}{l}\text { Gorongosa Restoration Project } \\
\text { / National Agency for } \\
\text { Conservation Areas (ANAC) }\end{array}$ & PA & Mozambique \\
\hline 20 & Gov't & Rwanda Development Board & PA & Rwanda \\
\hline 21 & Gov't & $\begin{array}{l}\text { Department of National Parks } \\
\text { and Wildlife }\end{array}$ & PA & Zambia \\
\hline 22 & Gov't & $\begin{array}{l}\text { Zimbabwe Parks and Wildlife } \\
\text { Management Authority }\end{array}$ & PA & Zimbabwe \\
\hline 23 & Non-profit & African Parks & National/international & International \\
\hline 24 & Non-profit & African Parks & National/international & International \\
\hline 25 & Non-profit & Frankfurt Zoological Society & National/international & International \\
\hline 26 & Non-profit & Worldwide Fund for Nature & National/international & International \\
\hline 27 & Non-profit & Wildlife Conservation Society & National/international & International \\
\hline 28 & Non-profit & Peace Parks Foundation & National/international & International \\
\hline 29 & Non-profit & Fauna and Flora International & National/international & International \\
\hline 30 & Non-profit & African Wildlife Foundation & National/international & International \\
\hline 31 & Non-profit & African Parks & National/international & International \\
\hline 32 & Non-profit & The Nature Conservancy & $\begin{array}{l}\text { National/international and } \\
\text { PA }\end{array}$ & $\begin{array}{l}\text { International } \\
\text { and Zambia }\end{array}$ \\
\hline 33 & Non-profit & African Parks & National/international & International \\
\hline 34 & Non-profit & Wildlife Conservation Society & $\mathrm{PA}$ & Mozambique \\
\hline 35 & Non-profit & Wildlife Conservation Society & National and PA & Madagascar \\
\hline 36 & Non-profit & African Wildlife Foundation & $\begin{array}{l}\text { National/international and } \\
\text { PA }\end{array}$ & Ethiopia \\
\hline 37 & Non-profit & Peace Parks Foundation & National and PA & Mozambique \\
\hline 38 & Non-profit & Worldwide Fund for Nature & PA & DRC \\
\hline 39 & Non-profit & Zoological Society of London & National and PA & Kenya \\
\hline 40 & Non-profit & Conservation Lower Zambezi & PA & Zambia \\
\hline 41 & Non-profit & African Parks & PA & $\begin{array}{l}\text { Zambia and } \\
\text { Malawi }\end{array}$ \\
\hline 42 & Non-profit & African Parks & PA & $\begin{array}{l}\text { Zambia and } \\
\text { Malawi }\end{array}$ \\
\hline 43 & Non-profit & Frankfurt Zoological Society & PA & Zambia \\
\hline 44 & Non-profit & Wildlife Conservation Society & $\begin{array}{l}\text { National/international and } \\
\text { PA }\end{array}$ & Congo \\
\hline 45 & Non-profit & African Parks & $\mathrm{PA}$ & DRC \\
\hline 46 & Non-profit & Frankfurt Zoological Society & PA & Zimbabwe \\
\hline 47 & Non-profit & Conservation Lower Zambezi & PA & Zambia \\
\hline 48 & Non-profit & $\begin{array}{l}\text { African Parks / formerly } \\
\text { Zambia Department of } \\
\text { National Parks and Wildlife }\end{array}$ & PA & Zambia \\
\hline 49 & Non-profit & Big Life Foundation & National and PA & Kenya \\
\hline 50 & Non-profit & Niassa Carnivore Project & $\mathrm{PA}$ & Mozambique \\
\hline 51 & Non-profit & Gorongosa Restoration Project & PA & Mozambique \\
\hline 52 & Non-profit & Wildlife Conservation Society & National and PA & Congo \\
\hline 53 & Non-profit & Frankfurt Zoological Society & PA & Ethiopia \\
\hline
\end{tabular}




\begin{tabular}{lllll}
\hline ID & Sector & Organisation & Level of expertise & Country \\
\hline 54 & Non-profit & Panthera & PA & Senegal and \\
& & & & Benin \\
55 & Non-profit & Conservation South Luangwa & PA & Zambia \\
56 & Non-profit & African Wildlife Foundation & PA & Uganda \\
57 & Non-profit & Game Rangers International & PA & Zambia \\
58 & Non-profit & Singita Grumeti Fund & PA & Tanzania \\
59 & Non-profit & Kasanka Trust Limited & PA & Zambia \\
60 & Non-profit & PAMS Foundation & PA & Tanzania \\
61 & Non-profit & African Parks & PA & Chad \\
62 & Non-profit & Peace Parks Foundation & National/international and & International \\
& & & PA & and Zambia \\
63 & Non-profit & Worldwide Fund for Nature & PA & CAR \\
64 & Non-profit & African Wildlife Foundation & National/international and & DRC \\
& & PA & Tanzania \\
65 & Non-profit & Wildlife Conservation Society & PA & Zambia \\
66 & Non-profit & Trident Foundation & PA & CAR \\
67 & Non-profit & African Parks / Chinko Project & PA & International \\
68 & Indep & Consultant & International & International \\
69 & Indep & Consultant & International & \\
\hline
\end{tabular}


Table S2. Protected area names.

\begin{tabular}{|c|c|}
\hline Protected area & Country \\
\hline Akagera National Park & Rwanda \\
\hline Bale Mountains National Park & Ethiopia \\
\hline Bangweulu Wetlands & Zambia \\
\hline Bili Uele Protected Area Complex & Democratic Republic of Congo \\
\hline Chinko Nature Reserve & Central African Republic \\
\hline Chyulu Hills National Park & Kenya \\
\hline Conkouati-Douli National Park & Democratic Republic of Congo \\
\hline Dzanga-Sangha Special Reserve & Central African Republic \\
\hline Garamba National Park & Democratic Republic of Congo \\
\hline Gile National Reserve & Mozambique \\
\hline Gonarezhou National Park & Zimbabwe \\
\hline Gorongosa National Park & Mozambique \\
\hline Ikorongo-Grumeti Game Reserve & Tanzania \\
\hline Kafue National Park & Zambia \\
\hline Kasanka National Park & Zambia \\
\hline Katavi National Park & Tanzania \\
\hline Kidepo Valley National Park & Uganda \\
\hline Lake Mburu National Park & Uganda \\
\hline Lavushi Manda National Park & Zambia \\
\hline Limpopo National Park & Mozambique \\
\hline Liuwa Plain National Park & Zambia \\
\hline Liwonde National Park & Malwai \\
\hline Lower Zambezi National Park & Zambia \\
\hline Majete Wildlife Reserve & Malawi \\
\hline Makira Natural Park & Madagascar \\
\hline Marakele National Park & South Africa \\
\hline Murchison Falls National Park & Uganda \\
\hline Niassa National Reserve & Mozambique \\
\hline Nkhotakota Game Reserve & Malawi \\
\hline North Luangwa National Park & Zambia \\
\hline Nouabale-Ndoki National Park & Congo \\
\hline Odzala-Kokoa National Park & Congo \\
\hline Ruaha National Park & Tanzania \\
\hline Salonga National Park & $\mathrm{DRC}$ \\
\hline Simien Mountains National Park & Ethiopia \\
\hline Sioma Ngwezi National Park & Zambia \\
\hline South Luangwa National Park & Zambia \\
\hline Tsavo West National Park & Kenya \\
\hline Virunga National Park & $\mathrm{DRC}$ \\
\hline W-Arly-Pendari (WAP) Complex & Benin \\
\hline West Lunga National Park & Zambia \\
\hline
\end{tabular}


Protected area

Zakouma National Park

Zinave National Park

\section{Country}

Chad

Mozambique 
Table S3. Recommendations for successful collaborative management partnerships.

\begin{tabular}{|c|c|}
\hline Theme & Key recommendations \\
\hline $\begin{array}{l}\text { Legal } \\
\text { agreement }\end{array}$ & $\begin{array}{l}\text { 1) Establish long-term legal agreements to build confidence among partners, donors, and potential investors. } \\
\text { 2) Ensure legal agreement clearly defines partner roles and responsibilities, sets out a clear process for decision-making, } \\
\text { and outlines staffing arrangements. } \\
\text { 3) Avoid overly-cumbersome governance structures that may inhibit effective and efficient functioning on the ground. }\end{array}$ \\
\hline $\begin{array}{l}\text { Financial } \\
\text { arrangements }\end{array}$ & $\begin{array}{l}\text { 1) Clearly and legally define extent of the commitment and definition of financial responsibilities of the partners, both in } \\
\text { terms of revenue generation and expenditure. } \\
\text { 2) Partners should strive for maximum financial transparency regarding income, budgets and expenditure. Fundraising can } \\
\text { be the cause of significant mistrust and friction if it is not undertaken transparently and with the involvement and blessing } \\
\text { of all partners. } \\
\text { 3) Particularly in the case of delegated and co-management models, mechanisms should be set up to retain revenues } \\
\text { generated from tourism (or other activities) at the PA level. Such mechanisms increase scope for financial sustainability, } \\
\text { reduce the financial liability of the non-profit partner and provide a degree of flexibility and rapidity in the allocation of the } \\
\text { PA's revenues that may not be the case where the state collects revenues centrally. }\end{array}$ \\
\hline Governance & $\begin{array}{l}\text { 1) Decision-making mechanisms should be clearly spelt out in the legal agreement established for the collaboration. } \\
\text { 2) The governing body should have a good balance of stakeholders to ensure that relevant interests are appropriately } \\
\text { represented, while keeping in mind that small and focused governing bodies are often more effective (and less costly) than } \\
\text { large and unwieldy ones, and that there are other mechanisms for collaboration with stakeholders who do not have formal } \\
\text { governance authority. } \\
\text { 3) Sufficient delegation of decision-making authority should be made to the management team to avoid frustration with } \\
\text { delays and to allow for adaptable management. } \\
\text { 4) Formal mechanisms for conflict resolution should be established in the event of disagreement and be embedded in the } \\
\text { legal agreement. } \\
\text { 5) All members of the governing body should be regularly informed of the overall aims of the collaboration and the } \\
\text { progress made toward those goals. }\end{array}$ \\
\hline
\end{tabular}




\begin{tabular}{|c|c|}
\hline Theme & Key recommendations \\
\hline Management & $\begin{array}{l}\text { 1) A general management plan and/or business plan should be collaboratively written and agreed to by both partners as a } \\
\text { pre-requisite for CMPs. Some parks also use jointly agreed annual operations plans to guide day-to-day management } \\
\text { activities. The plan should be approved by the relevant government authority, therefore forming a legal management } \\
\text { mandate. } \\
\text { 2) Long-term plans provide an important basis for identifying a shared vision for the management of the area in question, } \\
\text { and for defining strategies to achieve that vision. } \\
\text { 3) Management systems, including policies, procedures, standard operating procedures and, where relevant, codes of } \\
\text { conduct should be jointly developed and agreed by both partners. This provides a jointly agreed framework the } \\
\text { management team to work within. }\end{array}$ \\
\hline $\begin{array}{l}\text { Community } \\
\text { engagement }\end{array}$ & $\begin{array}{l}\text { Partners should: } \\
\text { 1) Engage communities from the development stages of implementing CMPs. } \\
\text { 2) Engage communities to understand their potential role in contributing to PA management and to understand their needs } \\
\text { before embarking on outreach programmes. } \\
\text { 3) Involve communities in the development of management plans for the PA. } \\
\text { 4) Employ staff with specialised community-related skills and/or engage partner organisations that specialise in community } \\
\text { work. } \\
\text { 5) Engage with local state agencies that have a mandate for community development. }\end{array}$ \\
\hline $\begin{array}{l}\text { Leadership and } \\
\text { staffing }\end{array}$ & $\begin{array}{l}\text { 1) Clearly and legally define the process for, and the non-profit's role in, hiring and firing of staff to ensure that only high } \\
\text { quality and motivated staff are employed and that there is a clear process for dealing with non-performing staff. } \\
\text { 2) Clearly and legally define roles, responsibilities, hierarchy, mode of interaction and decision-making protocols of staff. } \\
\text { This is especially important for co-management models where both partners are likely to want to select and employ PA } \\
\text { leadership. } \\
\text { 3) Both partners are advised to pay close attention to choosing staff who are able to collaborate effectively. } \\
\text { 4) To reduce conflict and jealousy, conditions of service of staff working for either partner should as far as possible be } \\
\text { aligned. } \\
\text { 5) To support effective collaboration, it is also important that shared performance management systems are put into place. }\end{array}$ \\
\hline
\end{tabular}




\section{Theme}

Interpersonal

relationships

\section{Key recommendations}

Partners should:

1) Work together to develop and implement planning frameworks that help ensure that all partners work towards a shared vision.

2) Ensure that agreements are long-term (especially for co- and delegated management models).

3) Ensure competent leadership.

4) Create effective and well-structured systems for communication.

5) Ensure effective monitoring of progress. Clear and measurable performance indicators reduce the risk of conflict or confusion about what each partner is contributing to the relationship. 


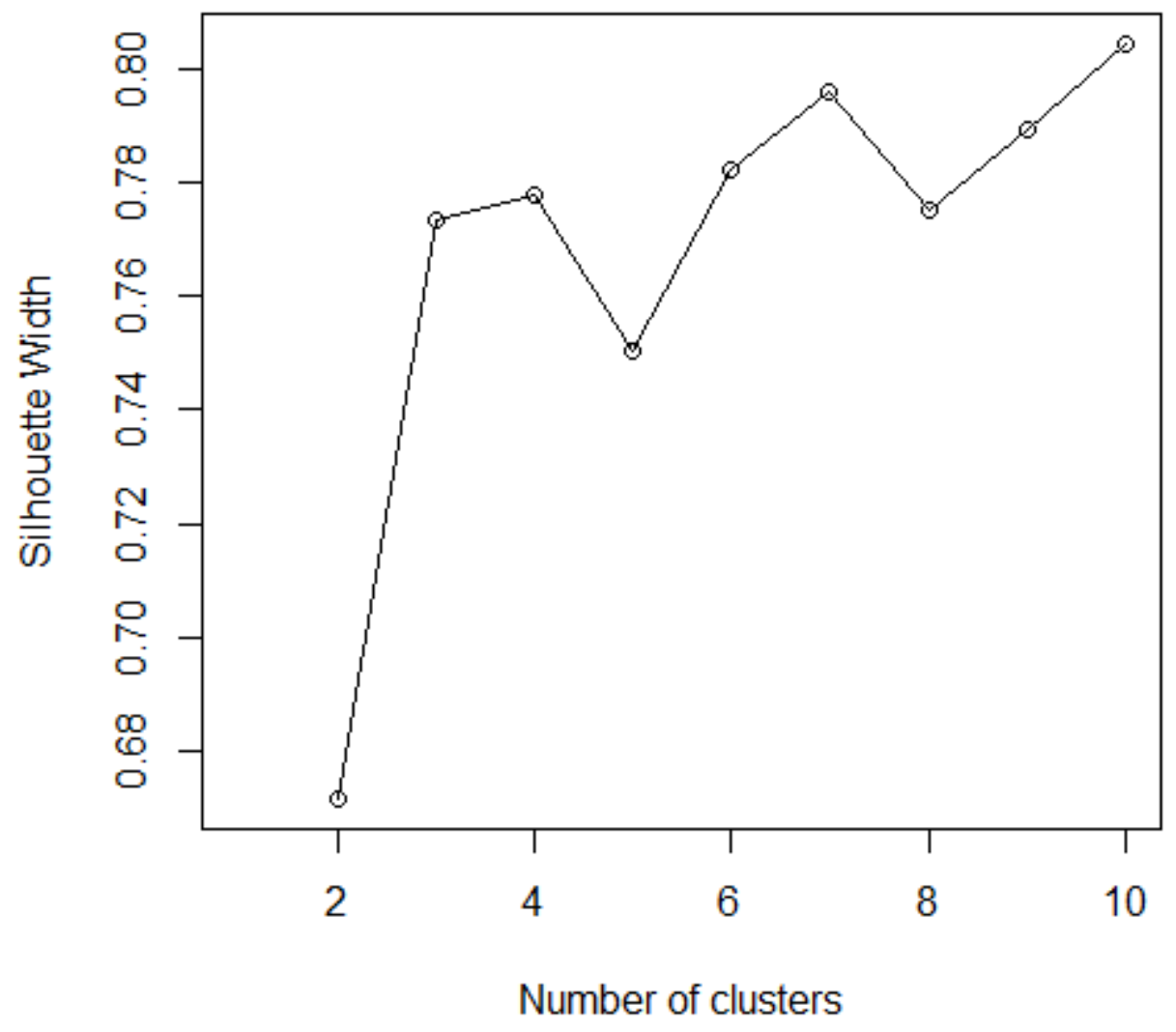

Figure S1. Results from silhouette width analysis, showing the optimal number of clusters. Statistical analysis identified 9 clusters as optimal, which we collapsed into 5 models (the second highest peak) to represent a working framework in order to match colloquial concepts of collaborative management partnerships (CMPs). 


\section{Cluster Dendrogram}

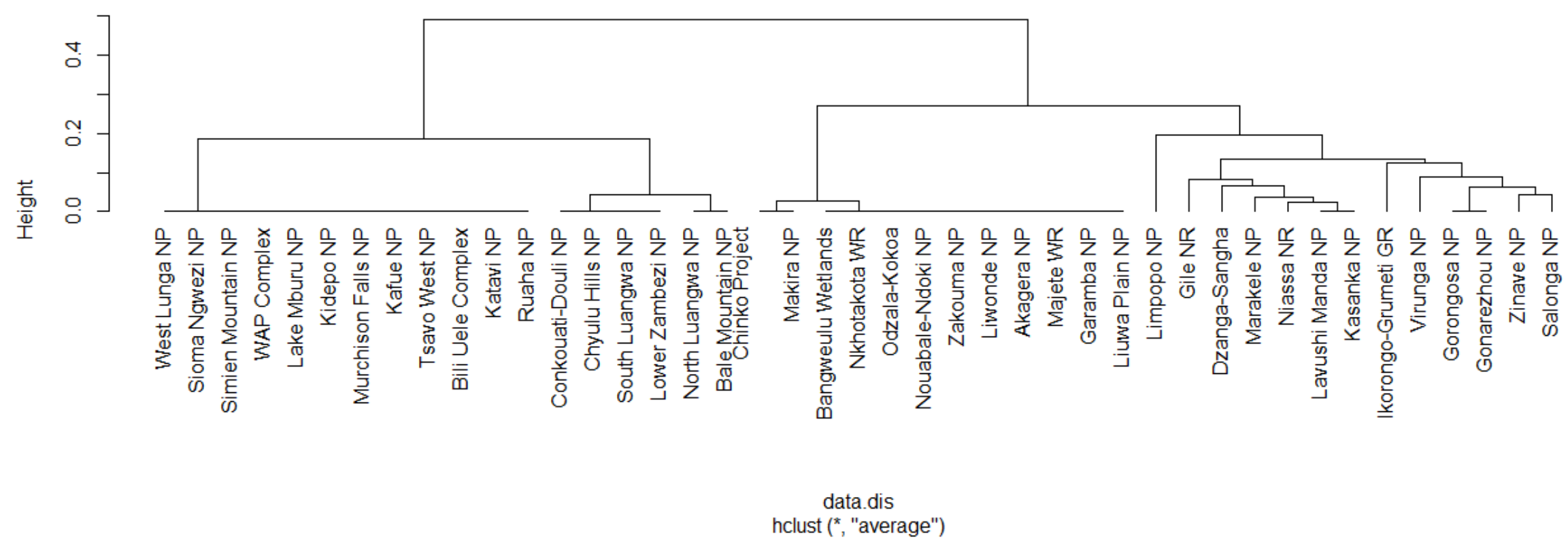

Figure S2. Principle Component Analysis cluster dendrogram of protected areas based on collaborative management partnership (CMP) characteristics, showing an optimal breakdown into ten models. We opted to organise protected areas into five CMP models (shown to split around the dendrogram height of 0.2 ) that show similar characteristics and closely related clustering. 